\title{
Yemeni Crisis Dynamics: Water Security and Possible Routes to Civilian Casualty Minimization
}

\author{
Darcy Pollard \\ Bard College at Simon's Rock, Great Barrington, Massachusetts, pollardarcy@gmail.com
}

\begin{abstract}
In a 2013 report released by the United Nations water insecurity was identified as a national security issue. This is due to the close correlation between mismanagement of water resources and acute conflict. With humanity's available potable water table under increasing stress from pressures like population growth, the effects of climate change and privatization, the potential for conflict to arise becomes more likely. This has been made painfully clear in Yemen, where a complex humanitarian crisis has evolved in recent years, called one of the worst crises of 2018. Disease, famine and conflict have spread rapidly, aggravated and in part induced by the consequences of being one of the most water-stressed countries in the world. This research examines the nature of the Yemeni crisis, particularly the role that water has played in it. It makes the case that in order for civilian casualties to be minimized, access to water must be protected.
\end{abstract}

KEYWORDS: crisis, defense, security, water, Yemen

\section{Introduction}

"Our children cry day and night because of the lack of food and clean water... There are times that I wish for death instead of living this life" (Abdelaziz 2017). The small, arid, Middle Eastern country of Yemen has been engaged in a brutal war since 2015. Following the Arab Spring in 2011, authoritarian president, Ali Abdullah Saleh was forced to leave office, giving power to Abdrabnuh Mansour Hadi. Hadi struggled to handle the failing Yemeni economy, the remaining loyalty to former president Saleh by many members of the military, water and food insecurity, as well as frequent attacks by al-Qaeda. Taking advantage of a vulnerable populous and weak government, the Houthi Movement, of Shia Muslim minority, began taking control of territory in the northern provence of Sa'dah. Many ordinary citizens joined the Houthi Movement (including Shias) as they became disenchanted by the transition and socio-economic state of Yemen. In early 2015, the Houthi rebels, as they became to be known, took control of the capital Sana'a (BBC News 2018). Yemen has a population of close to 29.3 million (USAID 2018). The crisis has left nearly 22 million in need of humanitarian assistance, 11.3 million of them being children (Ochab 2018). Due to blockades and destruction of infrastructure, the populace is in dire need of assistance. The conflict took an already fragile state and exacerbated the insecure conditions generating, the largest humanitarian crisis of 2018.

\section{Water Insecurity}

In 2012 the Water Stress index ranked Yemen as the seventh most water-stressed nation, receiving the distinction of "extreme risk" (Verisk Maplecroft 2012). Yemen has long battled with water insecurity and stress; in fact local urf (local shared knowledge of an Arabic Islamic society) has existed within Yemeni tribal tradition that prioritizes water resource management and sustainable usage practices. However these rules are unwritten and rely on voluntary engagement. There is little to no legal enforcement of water management guidelines by the Yemeni government, despite it being their second policy priority, following national security (The Hague Institute for Global Justice 2014). The present water insecurity dynamic is characterized by a confluence of challenges. Climate change has led to rainfall variability, with a decrease of average rainfall by 


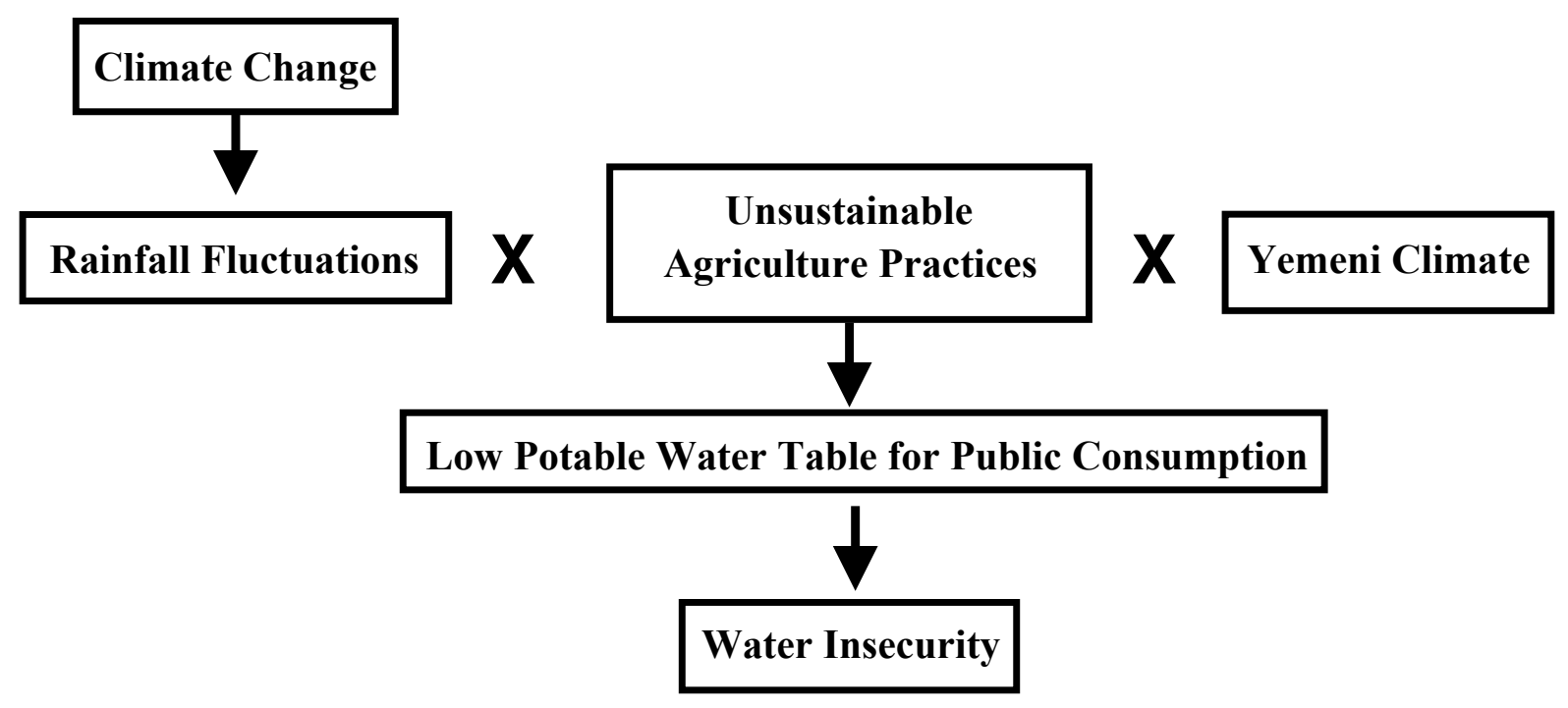

Figure 1. Dynamics of Water Insecurity in Yemen

$1.2 \mathrm{~mm}$ (a loss of 9\%) per month, per decade. This has the largest impact on the dry seasons, particularly in the Highlands. Climate change notwithstanding, rainfall varies greatly across the country, "from less than $50 \mathrm{~mm}$ along the coast, and rising with the topography to between 500 and $800 \mathrm{~mm}$ in the Western Highlands" (Mohamed et al. 2017). Additionally, the shifts in variability have led to the region facing at times drought and at others flooding (Brennan 2018). This is all made worse by the unsustainable agriculture practices that are popular in Yemeni industry. The agriculture industry uses $93 \%$ of potable drinking water, with qat production using $40 \%$ of that (Almas \& Scholz 2006). Qat is a leafy plant that is immensely popular in Yemen for its narcotic properties, "90\% of men and over a third of women habitually chew its leaves" (The Economist 2018). These issues of water access compounded with unsustainable agriculture practices result in a low potable water table for public consumption, as illustrated in figure 1.

\section{Food Insecurity}

This water insecurity operates as a catalyst for the food insecurity that is ravaging Yemen. Malnutrition has increased by 57\% since 2015 (Brennan 2018), 6.4 million rural people suffer from food insecurity and 1.1 million are deficient in food. Seventy percent of the Yemeni population rely on aid for survival, and nearly 400,000 children are at risk of death because of severe acute malnutrition. Access to food is in part affected by the decreased agricultural productivity that comes with water insecurity. The most potent illustration of this comes from the Highlands where the water table has shrunk dramatically and the majority of agricultural production occurs. They also are home to $70 \%$ of the population. Agriculture is the primary means of livelihood for the rural population, yet agriculture and related processing contribute only $13 \%$ to the GDP (Mohamed et al. 2017). Because of this, food must be sought elsewhere, with imports accounting for nearly $90 \%$ of Yemen's food supply (ReliefWeb 2009). 


\section{Conflict Factors}

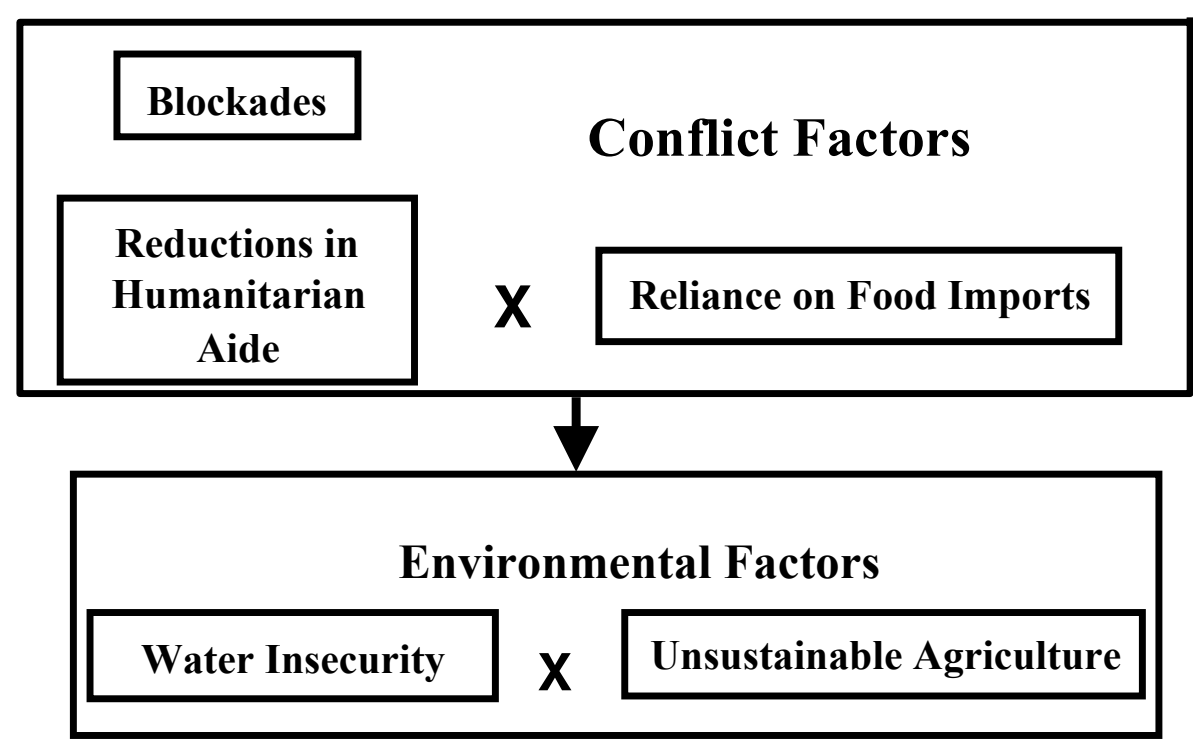

\section{$=$ Food Insecurity}

Figure 2. Factors Leading to Food Insecurity

This reliance on imports contributes to food insecurity as conflict cripples accessibility. Points of access and networks of distribution and trade have been destroyed in airstrikes and shelling, while those that survive are subject to blockades and access restriction. Access to the Al Hodaidah port was restricted in November 2016, a point of access that accounted for nearly 80\% of the imports to Yemen (World Food Programme 2017). This is a strategy that has been used by both Houthi and Saudi forces, blocking access to humanitarian aid, water, and food (Brown 2018). Water has been appropriated as a weapon of war.

\section{Disease}

In October of 2016, health authorities in Yemen confirmed an outbreak of cholera, concentrated in the country's capital, Sana'a (ReliefWeb. 2016 - UNICEF).

"Saudi aerial bombardment of the national electrical grid in April 2015 left the Sana'a wastewater plant without power. The plant ran on alternate fuel until the end of May 2015, and was then forced to shut down. UNICEF was able to keep it sporadically operating with fuel donations, but they weren't enough for full operations. Every time the plant shut down, untreated wastewater began to leak out into irrigation canals and drinking water supplies. By late summer 2015, the diarrhea outbreaks began. In October 2016, the first cases of cholera were reported. By the end of 2017, one million cases of cholera had been reported" (Shaikh 2018)

Bombings (by all conflict actors) of civilian infrastructure, has led to proliferation of disease. While largely spurred by the destruction of water treatment and sanitation facilities, hospitals are necessary to manage the outbreaks. In June of 2018 International Humanitarian Group, Doctor's Without Borders reported that a new cholera treatment center in Abs had been bombed by the "Saudi and Emirati-led coalition" (Doctors Without Borders 2018). Cholera may be the most prominent and directly linked to water, but other diseases have also been unrelenting during the conflict. As of January 2018, Doctors Without Borders reported that 10,291 cases of malaria had been treated since the start of the conflict in 2016 (ReliefWeb, January 2018). Disease spreads rapidly in war-torn regions as infrastructure crumbles 
and sanitation capabilities are diminished. In Yemen, families are forced to choose between food and medicine as poverty only worsens in conflict and access to critical supplies becomes scarce (Middle East Eye 2017).

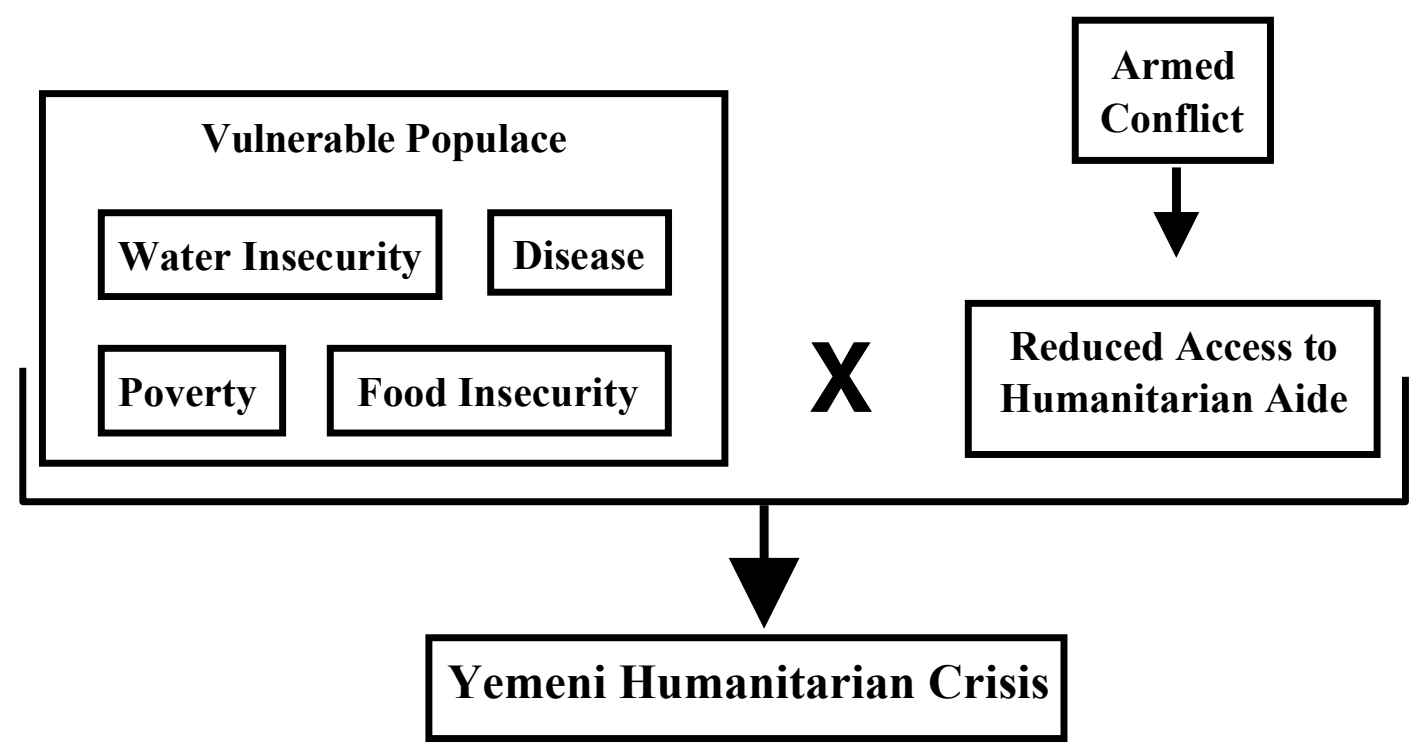

Figure 3. Yemeni Crisis Dynamics

\section{Population Vulnerability and Fragile Statehood}

The confluence of poverty-Yemen is a critically impoverished nation with $65 \%$ of its population living in poverty (Mohamed et al. 2017), water insecurity, food insecurity, and disease create a populace that is devastatingly vulnerable to armed conflict. Once civilians find themselves in such a conflict landscape, at times the only means of gaining access to resources like water and food are through active engagement. This is a real possibility in Yemen given the mutual use of water and food as weapons by both the Houthi rebellion and Saudi-led coalition forces (Brown 2018). Because of this dynamic, wherein all sides are engaged in manipulating resources that directly impact civilian lives, the question must become not, how can counter-insurgent policy neutralize the threat posed by the insurgency but, what steps can be taken to protect the civilians who are in an acute state of danger.

\section{Possible Interventions and Policy Recommendations}

Based on the dynamics of the Yemeni crisis as it is outlined in Figure 3, several things are clear: sustainable agriculture practices are essential for food and water security, thoughtful and sustainable use of water must be legislated in all governments in order to safeguard against water insecurity, and governments should encourage citizen engagement in the protection of their water resources. This is achievable through a diverse array of policy initiatives, including but not limited to: open source data collection, water resource location accessibility and public education on pollution and other obstacles to water potability. It is also important that governments examine the agricultural practices in their ecological and legal dimensions through the promotion and legal enforcement of using waste water for irrigation as opposed to potable drinking water, and by placing possible caps on water consumption for agriculture and other industries that heavily use water. These measures, if taken, would strengthen the society so that were it to enter an armed conflict, it could be less fractured. While these steps are effective as conflict impact reductions, the Yemeni crisis provides lessons for steps that must be taken to minimize civilian casualties during and post-conflict. These manifest in agreements between conflict actors and among members of the 
international community to protect civilians during conflict. This is achievable by the criminalization of civilian infrastructure destruction. Many pieces of infrastructure are destroyed as a cost of war, however, destruction of key pieces like water and sanitation treatment plants and hospitals will only result in the deaths of civilians. Losses could be minimized by designating such spaces as neutral territory safe from airstrikes. However, even with these pieces of infrastructure intact, they will be rendered obsolete if there is no way to supply them. For that reason it is necessary that conflict actors agree to suspend blockades that jeopardize civilian lives. Provisions must be made to allow civilians, particularly children, access to humanitarian aid, in the form of food, medicine, and water. Actors that prevent such resources from reaching civilians should be held accountable by the international community.

\section{Conclusion}

The impact of war on civilians is always tragic and often brutal, but steps may be taken to minimize casualties and prevent suffering. Water plays an important role in this as it is a basic human need and diminishing natural resource. If water access is protected prior to and during armed conflicts then, the devastating impact of war may be diminished. The crisis of Yemen is of catastrophic proportions and possesses a deep complexity. The recommendations and interventions offered are done so with the sole agenda of honoring those who have lost their lives to the Yemeni crisis, so that some small step may be taken to prevent similar suffering.

\section{Acknowledgements}

To my brother Ned, for showing the way.

\section{References}

Abdelaziz, Rowaida. 2017. “The Untold Story Of The Tiniest Victims Of Yemen's Brutal War.” Huffington Post, 13 July 2017. Huff Post, https://www.huffingtonpost.com/entry/yemen-war-children-malnutrition_us_59650ec1e4b03f144e2e6445.

Almas, Ahmed A. M., and Miklas Scholz. 2006. "Agriculture and Water Resources Crisis in Yemen: Need for Sustainable Agriculture.” Journal of Sustainable Agriculture 28(3): 55-75. DOI:10.1300/J064v28n03_06.

BBC News. 2018. "Yemen Crisis: Who Is Fighting Whom?”, 30 Jan. 2018. www.bbc.com, https://www.bbc.co.uk/news/ worldmiddle-east-29319423.

Brennan, Kailey. 2018. "Water Shortages Challenge Sustainable Agriculture in Yemen.” The Borgen Project, 6 Feb. 2018, https://borgenproject.org/sustainable-agriculture-in-yemen/.

Brown, Matt. 2018. “Amnesty Accuses Saudi-Led Forces and Houthi Rebels of Possible War Crimes.” ABC News, 22 June 2018, http://www.abc.net.au/news/2018-06-22/yemen-houthis-and-saudi-forces-hold- up-food-aid-fuel/9897684.

Doctors Without Borders. 2018. Yemen: Airstrike Hits MSF Cholera Treatment Center in Abs. Accessed 23 July 2018. https:// www.doctorswithoutborders.org/what-we-do/news-stories/story/yemen-airstrike-hits-msf-cholera-treatment-center- abs.

Middle East Eye. 2017. "Yemenis Forced to Choose between Treating Cholera and Eating, Says NGO.” Accessed 23 July 2018. http:// www.middleeasteye.net/news/yemenis-forced-choose-between-treating-cholera-or-feeding-families-ngo- says1241136453.

Mohamed, Hadil, et al. 2017. Yemen between the Impact of Climate Change and the Ongoing Saudi-Yemen War: A Real Tragedy. Centre for Governance and Peace-Building-Yemen, Nov. 2017, https://www.ru.nl/publish/pages/871321/ a_real_tragedy.pdf.

Ochab, Ewelina U. 2018. "Yemen Became The World's Worst Humanitarian Crisis." Forbes. Accessed 24 July 2018. https://www.forbes.com/sites/ ewelinaochab/2018/04/05/yemen-became-the-worlds-worst-humanitarian-crisis/.

ReliefWeb. 2009. "Drought and Floods in Yemen Affect Food Security." Accessed 23 July 2018. https://reliefweb.int/report/yemen/drought-and-floods-yemen-affect-food-security.

ReliefWeb. 2016. Yemen Cholera Outbreak Situation Report \#1. UNICEF, 11 Oct. 2016, https://reliefweb.int/report/yemen/ yemen-cholera-outbreak-situation-report-1.

ReliefWeb. 2018. "Yemen: Crisis Update - January 2018." https://reliefweb.int/report/yemen/yemen-crisis-update - January2018. Accessed 24 July 2018.

Shaikh, Alanna. 2018. "Yemen Is Currently Facing the Largest Documented Cholera Epidemic in Modern Times. A New Report Warns It Could Get Worse." UN Dispatch, 8 May 2018. https:/www.undispatch.com/yemen- is-currently-facing-thelargest-documented-cholera-epidemic-in-modern-times-a-new-report-warns-it-could-get- worse/. 
The Economist. 2018. “The Drug That Is Starving Yemen.” January 2018. https://www.economist.com/ middle-east-andafrica/2018/01/04/the-drug-that-is-starving-yemen.

The Hague Institute for Global Justice. 2014. The Political Economy of Water Management in Yemen:Conflict Analysis and Recommendations., 25 June 2014, pp. 66, 179, 180, http://www.yemenwater.org/wp-content/uploads/2015/06/ThePolitical-Economy-of-Water-Management-in-Yemen.pdf.

USAID. 2018. Yemen - Complex Emergency, Fact Sheet \#8. 8 June 2018, https://www.usaid.gov/crisis/yemen.

Verisk Maplecroft. 2012. Water Stress Index 2012. Accessed $23 \quad$ July 2018. https://www.maplecroft.com/about/news/water_stress_index_2012.html.

World Food Programme. 2017. State of Food Insecurity in YEMEN Based on the Emergency Food Security and Nutrition Assessment (EFSNA). Apr. 2017, https://documents.wfp.org/stellent/groups/public/documents/ena/ wfp291809.pdf?_ga=2.55100267.1349820371.1531950417-1394190354.1531950417. 